\title{
Ease Of Use Dan Trust Terhadap Purchase Intention Melalui Customer Satisfaction Pada Situs Web Tokopedia
}

\author{
Juliana $^{1}$, Themmy Noval ${ }^{2}$,Ira Brunchilda Hubner ${ }^{3}$,Innocentius Bernarto ${ }^{4}$ \\ ${ }^{1}$ Universitas Pelita Harapan, juliana.stpph@uph.edu \\ ${ }^{2}$ Pradita Institute, themmyn@gmail.com \\ ${ }^{3}$ Universitas Pelita Harapan, ira.hubner@uph.edu \\ ${ }^{4}$ Universitas Pelita Harapan, bernarto227@gmail.com
}

\begin{abstract}
ABSTRAK
Penelitian ini bertujuan untuk menganalisis variabel ease of use merupakan prediktor positif atas purchase intention, untuk menganalisis variabel ease of use merupakan prediktor positif atas customer satisfaction, untuk mengalisis apakah trust merupakan prediktor positif atas purchase intention, untuk menganalisis apakah trust merupakan prediktor positif atas customer satisfaction serta untuk menganalisis apakah customer satisfaction merupakan prediktor positif atas purchase intention. Populasi yang digunakan dalam penelitian ini adalah seluruh pengguna situs web atau aplikasi tokopedia di Indonesia. Mengingat banyaknya pengguna situs web atau aplikasi tokopedia maka peneliti mengambil sampel dari populasi untuk dijadikan responden dalam penelitian. Sampel penelitian ini dikumpulkan dari pelanggan yang menggunakan situs web atau aplikasi Tokopedia dan berdomisili di daerah Jabodetabek. Pengujian hipotesis dilakukan dengan data utama sebanyak 300 responden. Teknik dalam pengambilan sampel dalam penelitian ini menggunakan teknik probability sampling. Jenis probability sampling yang digunakan adalah metode simple random sampling. Analisis statistic dengan pendekatan partial least square-structural equation modeling (PLS-SEM) untuk mengukur variabel independen merupakan predictor positif dan signifikan atas variabel dependen. Hasil penelitian menunjukkan bahwa seluruh hipotesis tidak ditolak. Implikasi penelitian menitikberatkan pada fungsi nyata dari hasil penelitian untuk memberikan referensi tambahan dalam menetapkan peran customer satisfaction sebagai pemediasi trust dan ease of use dengan purchase intention pada situs web Tokopedia
\end{abstract}

Kata Kunci : ease of use, trust, purchase intention, customer satisfaction

\section{ABSTRACT}

This study aims to analyze the ease of use variable which is a positive predictor of purchase intention, to analyze the ease of use variable is a positive predictor of customer satisfaction, to analyze whether trust is a positive predictor of purchase intention, to analyze whether trust is a positive predictor of customer satisfaction. and to analyze whether customer satisfaction is a positive predictor of purchase intention. The population used in this study were all users of the Tokopedia website or application in Indonesia. Given the large number of users of the Tokopedia website or application, the researchers took a sample from the population to become respondents in the study. This research sample was collected from customers who use the Tokopedia website or application and live in the Jabodetabek area. Hypothesis testing is done with the main data of 300 respondents. The sampling technique used in this study was probability sampling. The type of probability sampling used is the simple random sampling method. Statistical analysis using the partial least square-structural equation modeling (PLSSEM) approach to measure the independent variable is a positive and significant predictor of the dependent variable. The results showed that all hypotheses were not 
rejected. The research implication focuses on the real function of the research results to provide additional references in determining the role of customer satisfaction as a mediator of trust and ease of use with purchase intention on the Tokopedia website Keywords: ease of use, trust, purchase intention, customer satisfaction

Naskah diterima : 27-08-2020, Naskah direvisi : 17-02-2020 Naskah dipublikasikan :0109-2020

\section{PENDAHULUAN}

Seiring berjalannya waktu, teknologi dan internet sudah semakin berkembang dan menjadi salah satu alat atau media yang digunakan untuk berbagai keperluan dan kebutuhan. Salah satu contoh dari penggunaan teknologi yang dilengkapi dengan manfaat internet adalah $e$ commerce. E-Commerce mengacu kepada pemrosesan transaksi, seperti membeli dan menjual produk dan layanan melalui jaringan computer seperti internet. $E$ Commerce tidak hanya memperhatikan fungsi membeli dan menjual barang dan layanan secara online, akan tetapi juga memfasilitasi keseluruhan proses pembelian dan penjualan baik untuk penjual maupun pembeli. Secara umum, e-commerce adalah aktivitas bisnis yang beroperasi melalui media elektronik seperti internet.

Pertumbuhan e-commerce memiliki banyak keunggulan dibandingkan toko tradisional, termasuk fleksibilitas yang lebih tinggi, jangkauan pasar yang lebih luas dan baik, struktur biaya yang lebih rendah, transaksi lebih cepat, lini produk yang lebih luas, kenyamanan yang lebih besar, dan kustomisasi (Nisar \& Prabhakar, 2017). Menurut data Asosiasi Penyelenggara Jasa Internet Indonesia (APJII), pengguna internet sebagian besar memiliki dan menggunakan aplikasi atau konten jejaring sosial sebesar $87,4 \%$, kedua adalah searching $68,7 \%$ ketiga instan messaging $59,9 \%$, keempat mencari berita terkini $59,7 \%$, dan kelima mendownload dan meng-upload video $27,3 \%$. Ditinjau dari jenis situs yang digunakan untuk berjualan online, $64,9 \%$ menggunakan jejaring sosial, 22,9\% messenger, $14,4 \%$ komunitas online, $5,7 \%$ blog toko online, $2,3 \%$ website toko online, dan 1,5\% mailist (Hidayat \& Kristiana, 2016) Sebanyak 62 juta orang menggunakan media sosial, dan sekitar 4,6 juta konsumen di Indonesia yang menggunakan internet secara aktif untuk bertransaksi atau berbelanja. Teknologi digital telah mengubah cara manusia dalam berbicara, berkomunikasi, bertindak dan mengambil keputusan. Digital marketing merupakan salah satu media pemasaran yang satu ini sedang banyak diminati oleh masyarakat untuk mendukung berbagai kegiatan yang dilakukan. Masyarakat sedikit demi sedikit mulai meninggalkan model pemasaran konvensional atau tradisional dan beralih ke pemasaran modern yaitu digital marketing. Digital marketing merupakan kegiatan marketing termasuk branding yang menggunakan media berbasis web seperti blog, website, e-mail , adwords ataupun jejaring sosial. Tentu saja digital marketing bukan hanya berbicara mengenai internet marketing (Pradiani, 2018)

Pemahaman oleh (Laudon, K., dan Laudon, 2013) e-commerce yaitu media perdagangan elektronik yang memiliki sifat-sifat tertentu. Berdasarkan sifat penggunanya, e-commerce dapat dibagi menjadi beberapa tipe, yaitu business-tobusiness(B2B), business-to-consumer (B2C), consumer-to-consumer (C2C). Dengan masuknya perkembangan digital di Indonesia membuat hampir seluruh sector industry menggunakan internet untuk dapat menjadi sumber penyebaran informasi ditambah 50 persen penduduk Indonesia yang menggunakan internet menjadi keuntungan untuk masyarakat Indonesia memanfaatkan fasilitas dan memulai bisnis yang berbasis internet atau e-commerce. Perantara berbasis online (internet) seperti Lazada, Tokopedia, Shoppee, Buka Lapak, JD.id dan lain sebagainya, membantu mengurangi beban biaya yang harus dikeluarkan untuk 


\section{Jurnal Ecodemica, Vol. 4 No. 2 September 2020}

kegiatan pemasaran atau promosi. Tokopedia merupakan salah satu marketplace online terbesar di Indonesia yang membantu pengguna internet dalam melakukan transaksi jual beli online. Tokopedia menduduki peringkat ke-3 sebagai situs e-commerce terbaik di Indonesia. Tokopedia merupakan toko online yang menawarkan segudang fitur serta layanan cepat yang memengaruhi kemudahan penggunaan aplikasi terhadap niat beli pada konsumen di Tokopedia. Niat beli pada konsumen Tokopedia juga tidak terlepas kemudahan dalam melakukan akses serta privasi yang tinggi yang merupakan bagian dari kualitas website yang dimiliki Tokopedia.

Tokopedia juga menerapkan review atau ulasan yang bertujuan untuk memberikan berupa pengalaman atau kesan pembelian oleh konsumen setelah melakukan purchase di Tokopedia. Niat beli secara online merupakan bagian dari komponen perilaku konsumen online melalui rencana konsumen dengan kecenderungan untuk membeli suatu produk melalui internet atau mengambil tindakan sebelum keputusan membeli benar-benar dilakukan. Dengan ratusan ribu pilihan produk tersedia dari berbagai kategori yaitu kesehatan dan kecantikan, peralatan rumah tangga,elektronik, handphone dan masih banyak lagi. Terdapat banyak faktor yang memengaruhi niat beli konsumen terhadap toko online Tokopedia seperti brand image, price, trust dan value.

Kepercayaan juga menjadi salah satu faktor yang menentukan keputusan konsumen dalam melakukan keputusan pembelian (Kooli et al., 2014) .Penyebab konsumen cenderung tidak melakukan belanja melalui aplikasi atau situs web adalah kesusahan dalam navigasi halaman dan kepercayaan. Harapan konsumen harus terpenuhi agar konsumen merasa puas dan kepuasan dapat meningkatkan niat pembelian. Penelitian ini juga didukung oleh (Eid, 2011) yang menguji secara empiris kepercayaan pelanggan, kepuasan dan sikap loyalitas pelanggan
B2C di Arab Saudi dan sangat dipengaruhi oleh kepuasan pelanggan tetapi lemah dipengaruhi oleh kepercayaan pelanggan. Peneliti yang lain adalah (Amin et al., 2014) di mana penelitiannya bertujuan untuk mengetahui pengaruh kemudahan penggunaan dan manfaat yang dirasakan terhadap kepuasan konsumen dengan kepercayaan sebagai mediasi. Penelitian yang dilaksanakan oleh (Kirwadi, 2016) menyatakan bahwa perceived ease of use berpengaruh signifikan dan positif terhadap purchase intention, serta trust berpengaruh signifikan dan positif terhadap purchase intention. Penelitian yang dilakukan oleh (Julianto, 2012) menyatakan bahwa customer satisfaction berpengaruh terhadap purchase intention. Serta penelitian dilakukan oleh (Vinjeng Purnama Putri, 2019) menyatakan bahwa trust dan customer satisfaction berpengaruh terhadap repurchase intention. Penelitian dilakukan oleh (Banjarnahor, 2018) menyatakan bahwa terdapat pengaruh positif antara customer satisfaction dengan purchase intention. Tingginya niat beli masyarakat Indonesia mendorong e-commerce tumbuh semakin pesat untuk menyediakan laayanan yang diinginkan konsumen. Penelitian ini membahas niat beli masyarakat melalui situs web Tokopedia yang dipilih sebagai situs yang sering dikunjungi oleh konsumen dalam pemesanan online. Rumusan masalah penelitian meliputi apakah ease of use merupakan prediktor yang positif dan signifikan atas purchase intention pada situs web Tokopedia?, apakah ease of use merupakan prediktor yang positif dan signifikan atas customer satisfaction pada situs web Tokopedia?, apakah trust merupakan prediktor yang positif dan signifikan atas purchase intention pada situs web Tokopedia?,apakah trust merupakan prediktor yang positif dan signifikan atas purchase intention pada situs web Tokopedia?, apakah customer satisfaction merupakan prediktor yang positif dan signifikan atas purchase intention pada 


\section{Jurnal Ecodemica, Vol. 4 No. 2 September 2020}

situs web Tokopedia? Tujuan penelitian untuk menganalisis apakah ease of use merupakan prediktor yang positif dan signifikan atas purchase intention pada situs web Tokopedia, untuk menganalisis apakah ease of use merupakan prediktor yang positif dan signifikan atas customer satisfaction pada situs web Tokopedia, untuk menganalisis apakah trust merupakan prediktor yang positif dan signifikan atas purchase intention pada situs web Tokopedia,untuk menganalisis apakah trust merupakan prediktor yang positif dan signifikan atas purchase intention pada situs web Tokopedia, untuk menganalisis apakah customer satisfaction merupakan prediktor yang positif dan signifikan atas purchase intention pada situs web Tokopedia?

\section{KAJIAN LITERATUR}

Theory of Reasoned Action (TRA) dikembangkan untuk lebih memahami hubungan antara sikap, niat, dan perilaku. TRA mengasumsikan bahwa penentu perilaku langsung yang paling penting adalah niat perilaku. Keberhasilan teori dalam menjelaskan perilaku bergantung pada sejauh mana perilaku berada di bawah kontrol kesusilaan, artinya individu dapat menggunakan kontrol tingkat tinggi atas perilaku tersebut (Montano, D. E., \& Kasprzyk, 2015) Penelitian dilakukan oleh (Amaro, Suzanne \& Duarte, 2015) PBC diuraikan menjadi dua komponen yaitu self-efficacy yang didefinisikan sebagai penilaian dari konsumen atas kemampuan konsumen sendiri untuk belanja secara online dan controllability yang didefinisikan sebagai penilaian individu tentang ketersediaan sumber daya dan kesempatan untuk belanja online. Penelitian oleh (Bukhari, S. M. F., Ghoneim, A., Dennis, C., \& Jamjoom, 2013) menyatakan bahwa terdapat sembilan kontruksi dalam mengukur kepuasan konsumen dan niat untuk membeli tiket dari situs web yang meliputi information quality, system quality, perceived usefulness, perceived ease of use, e-trust, airline reputation, price perception, e-satisfaction and intention to purchase. Ease of Use menurut (Tandon et al., 2016) menyatakan ease of use terhadap belanja online mengacu kepada sejauh mana pemahaman, pembelajaran dan pengoperasian sistem atau teknologi terntentu bebas dari usaha fisik dan mental.

Penelitian menurut (Sin et al., 2012) ease of use adalah derajat dimana seseorang percaya bahwa menggunakan sistem tertentu akan bebas dari usaha. Menurut (Rodrigues, L. F., Oliveira, A., \& Costa, 2016) ease of use didefinisikan sebagai sejauh mana pengguna percaya bahwa menggunakan sistem informasi akan bebas dari kesusahan. Penelitian oleh (Ozturk, A. B., Bilgihan, A., Nusair, K., \& Okumus, 2016) ease of use didefinisikan sebagai sejauh mana seseorang percaya bahwa penggunaan sistem tertentu bebas dari kesusahan seperti mudah dipahami atau digunakan. Dari pemahaman di atas, dapat disimpulkan bahwa kemudahan penggunaan adalah suatu istilah yang dapat dipahami dan digunakan dengan mudah untuk suatu teknologi yang masih asing atau baru agar konsumen tidak merasa kesulitan dalam menggunakannya.

Trust menurut (Choon Ling, K., Bin Daud, D., Hoi Piew, T., Keoy, K. H., \& Hassan, 2011; Martínez, P., \& del Bosque, 2013 ; Oliveira et al., 2017;Xu, J., Cenfetelli, R.T., \& Aquino, 2016) menyatakan trust/kepercayan terbentuk ketika konsumen mempunyai kepercayaan bahwa mitra transaksi akan berperilaku baik dan dengan cara yang baik, walaupun penerimaan kepercayaan melibatkan pengambilan risiko tertentu sehingga kepentingan jangka panjang konsumen akan dilayani. Trust merupakan suatu keyakinan dari konsumen terhadap suatu barang atau jasa yang diberikan atau diterima. Pemahaman menurut (McKecnie et al., 2011) variabel customer satisfaction diukur dengan empat dimensi yakni 


\section{Jurnal Ecodemica, Vol. 4 No. 2 September 2020}

overall (secara keseluruhan) right choice (pilihan yang tepat) meet expectations (memenuhi harapan) dan delighted (sangat senang).

Pemahaman menurut (Abd-El-Salam, E. M., Shawky, A. Y., \& El-Nahas, 2013) customer satisfaction telah muncul sebagai salah satu alat yang paling ampuh untuk mempertahankan keunggulan kompetitif bagi kesuksesan bisnis dan kelangsungan hidup saat ini, melalui kualitas layanan yang baik.

Beberapa pemahaman menurut (Abd-ElSalam, E. M., Shawky, A. Y., \& ElNahas, 2013; Jiang \& Zhang, 2016; Orel, F. D., \& Kara, 2014; Pham \& Ahammad, 2017; Rashid, I. M. A., Abdullah, M. F. S., Yusuf, B. N. M., \& Shaari, 2016; Taufiqurrahman, 2015) customer satisfaction merupakan sejauh mana kinerja yang dirasakan produk sesuai dengan harapan pembeli dan sebagai perbandingan pembeli secara berulang dan biaya pembelian sehubungan dengan konsekuensi yang diantisipasi.Menurut (Qureshi, M. N. Z., \& Bhatt, 2015) customer satisfaction menunjukkan kemampuan penyedia layanan memberikan kepuasan sesuai dengan harapan pembeli.Dari seluruh pengertian diatas, dapat disimpulkan bahwa kepuasan pelanggan adalah suatu penilaian pelanggan terhadap produk atau pelayanan yang telah memberikan tingkat kenikmatan seperti yang diharapkan.

Menurut (Platon, O. E., Iosub, I., \& Ditoiu, 2014) menyatakan model AIDA merupakan unsur purchase intention tetapi dalam masalah penelitian ini berhubungan dengan internet dan sosial media, dimana ditambahkan satu unsur yakni tell sehingga ditetapkan model AIDAT (Attention, Interest, Desire, Action, Tell)

Pengertian oleh (Mirabi, V., Akbariyeh, H., \& Tahmasebifard, 2015; Wang, Y. H., \& Tsai, 2014) purchase intention merupakan situasi /kemungkinan yang ada di sisi konsumen dimana konsumen cenderung membeli produk tertentu dalam kondisi tertentu.
Dari pemahaman di atas maka purchase intention merupakan keinginan atau hasrat untuk memenuhi kebutuhan dengan membeli objek tersebut, di mana ada suatu perasaan tertarik terhadap objek tersebut, dan untuk mendapatkannya konsumen rela menghabiskan sejumlah uang.

\section{Ease of Use dengan Customer Satisfaction}

Menurut (Amin et al., 2014; Pham \& Ahammad, 2017) menyatakan bahwa Ease of Use mempunyai pengaruh positf terhadap customer satisfaction. Situs ritel yang berperforma buruk tidak memenuhi harapan konsumen untuk kenyamanan, sehingga pelanggan sudah pasti tidak puas dengan waktu berbelanja di situs web tersebut. Keramahan dan situs web yang mudah digunakan dapat membuat pelanggan puas dalam berbelanja.

Kemudahan penggunaan dianggap sebagai faktor penting bagi pengembangan perdagangan elektronik. Pencarian produk dan informasi produk adalah dua atribut penting untuk menghasilkan peringkat positif dari ritel online. Pelanggan yang tidak merasa kesusahan dalam pencarian produk dan informasi dapat meningkatkan kepuasan dalam belanja.

\section{Ease of Use dengan Purchase Intention}

Penelitian oleh (Sin et al., 2012; Law, M., Kwok, R.C., \& Ng, 2016; Wu \& Ke, 2015) mengungkapkan bahwa kemudahan penggunaan berpengaruh signifikan terhadap niat pembelian. Pelanggan cenderung membeli secara online melalui media sosial jika proses penggunaan media sosial dalam hal pemesanan dan pengiriman produk atau layanan sederhana dan mudah dimengerti. Jika situs media sosial sulit dinavigasi dan rumit, maka pelanggan membutuhkan banyak waktu dan usaha untuk belajar sehingga mungkin konsumen menjadi tidak nayaman dan bisa menyebabkan frustrasi. Jika pengguna pelanggan dapat mengunjungi halaman web dengan mudah, maka 


\section{Jurnal Ecodemica, Vol. 4 No. 2 September 2020}

pelanggan akan memiliki niat yang lebih tinggi untuk membeli secara online. Orang yang tidak memerlukan usaha tambahan dalam menggunakan teknologi tertentu akan meningkatkan niat pembelian dalam belanja online.

\section{Trust dengan Customer Satisfaction}

Studi menurut (Martínez, P., \& del Bosque, 2013; Pappas et al., 2014; Tahir Jan \& Abdullah, 2014) mengemukakan bahwa kepercayaan dan kepuasan sangat erat kaitannya satu sama lain. Seseorang dapat membangun kepercayaan dalam sebuah organisasi berdasarkan kata-kata positif dari mulut ke mulut, periklanan, dan jenis komunikasi lainnya. Hal ini akan memberi pengaruh positif terhadap penilaiannya terhadap organisasi tersebut. Oleh karena itu, kepercayaan terhadap suatu organisasi akan menciptakan sikap positif dan meningkatkan kepuasan. Kepercayaan dianggap penting di sektor jasa, terutama bila teknologi digunakan terutama untuk berinteraksi dengan pelanggan. menemukan hubungan positif yang signifikan antara kepercayaan dan kepuasan pelanggan. Dapat disimpulkan kepercayaan adalah prediktor terkuat dari kepuasan pelanggan.

\section{Trust dengan Purchase intention}

Penelitian oleh (Choon Ling, K., Bin Daud, D., Hoi Piew, T., Keoy, K. H., \& Hassan, 2011; Lien, C. H., Wen, M. J., Huang, L. C., \& Wu, 2015) menemukan bahwa kepercayaan merupakan faktor penting dalam memengaruhi niat beli. Ketika konsumen memiliki tingkat kepercayaan yang lebih tinggi kepada penjual, maka konsumen akan memperoleh tingkat minat beli yang lebih tinggi.

Komitmen dan kepercayaan secara signifikan memoderasi hubungan antara niat pembelian konsumen dan perilaku belanja internet juga memiliki pengaruh langsung pada perilaku belanja online..

\section{Customer satisfaction dengan Purchase intention}

Penelitian menurut (Alavi et al., 2016; Ali, F., \& Ali, 2016; Herrera \& Blanco, 2011) menganggap kepuasan pelanggan sebagai penilaian terhadap suatu produk, fitur layanan atau produk atau layanan itu sendiri berdasarkan pengalaman interaksi pelanggan. Kepuasan pelanggan bukan akhir, melainkan sarana untuk mencapai tujuan, termasuk niat dan loyalitas pembelian pelanggan. Hubungan antara kepuasan dan niat pelanggan telah mendapat banyak perhatian dalam berbagai konteks bisnis offline maupun online.

\section{Hasil Penelitian Relevan}

Penelitian oleh (Amin, M., Rezaei, S., \& Abolghasemi, 2014) Hasil penelitian menunjukkan bahwa ada hubungan positif antara PEOU, PU dan mobile users' satisfaction. PU secara positif terkait dengan trust dan mobile users, satisfaction. Selain itu, trust berpengaruh positif terhadap mobile users' satisfaction.

Penelitian menurut (Sin et al., 2012) hasil penelitian menunjukkan bahwa perceived usefulness merupakan faktor yang paling dominan mempengaruhi niat pembelian online konsumen muda melalui media sosial, diikuti oleh kemudahan penggunaan dan norma subjektif. Penelitian oleh (Suki, 2011) menunjukkan responsiveness berpengaruh signifikan terhadap kepuasan, brand image berpengaruh signifikan terhadap kepuasan, kepuasan berpengaruh signifikan terhadap kepercayaan, sedangkan ease of use, usefulness, customisation, dan interactivity tidak berpengaruh signifikan terhadap kepuasan. 


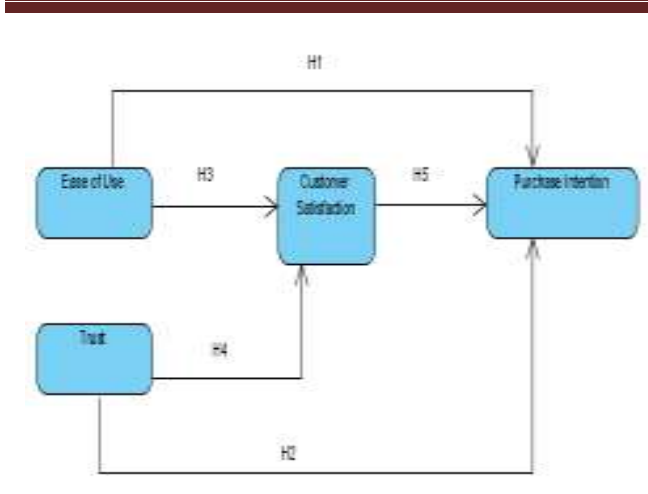

Gambar 2. Rerangka pemikiran Sumber: Hasil Olahan Data (2020)

Berdasarkan teori dan penelitian terdahulu yang dikemukakan di atas, maka dibuat hipotesis sebagai berikut:

H1: Ease of Use merupakan prediktor yang positif dan signifikan atas purchase intention

H2: Trust merupakan prediktor yang positif dan signifikan atas purchase intention

H3: Ease of Use merupakan prediktor yang positif atas customer satisfaction

$\mathrm{H}_{4}$ : Trust merupakan prediktor yang positif atas customer satisfaction

$\mathrm{H}_{5}$ : Customer satisfaction merupakan prediktor yang positif atas purchase intention

\section{METODE PENELITIAN}

Sebelum memulai penelitian dan membangun rumusan masalah telah dilakukan pretest awal terhadap pengguna situs web Tokopedia dan jumlah responden untuk pre-testing adalah sebesar 50 responden, hasil yang didapat dari pretest tersebut menyatakan semua pertanyaan yang akan digunakan bersifat valid dan dapat digunakan sebagai kuesioner dalam penelitian. Penelitian ini merupakan penelitian yang bersifat asosiatif menggunakan pendekatan deskriptif kuantitatif dengan variabel independennya trust dan ease of use serta variabel dependennya purchase intention, variabel mediasi customer satisfaction menggunakan pendekatan partial least square-structural equation modeling (PLS-SEM). Penelitian di mulai dari mengumpulkan, mengukur dan menganalisa data dengan populasi merujuk seluruh konsumen yang pernah menggunakan situs web Tokopedia atau aplikasi tokopedia di Indonesia yang digunakan dalam penelitian ini adalah metode probability sampling dengan jenis metode simple random sampling jumlah responden adalah sebanyak 300 orang.Dalam penelitian ini dilaksanakan pengujian validitas dan reliabilitas dilaksanakan sebelum mengevaluasi model penelitian ini.. Uji validitas dengan melihat average variance extracted (AVE) dan factor loadings (outer loadings. Nilai minimal yang harus didapatkan untuk AVE dan outer loadings masing-masing sebesar 0,5 dan 0,7 (Hair et al., 2014) dilanjutkan dengan discriminant analysis dimana yang harus diperhatikan mengikuti kriteria dari Farnel Larcker dimana nilai akar AVE harus lebih besar dari nilai korelasi antara konstruk (Hair et al., 2014)

\section{PEMBAHASAN}

Hasil pengolahan data memperlihatkan bahwa seluruh instrument penelitian dinyatakan valid. Hasil perhitungan memperlihatkan bahwa nilai AVE 0.567 sampai 0.620. Untuk nilai factor loadings atau outer loadings yakni 0.510 hingga 0.865 dimana nilai outer loadings antara 0.4 hingga 0.7 dapat dipertahankan sepanjang dapat meningkatkan nilai AVE (Hair et al., 2014) . Kemudian uji reliabilitas dilaksanakan dengan memperhatikan rekomendasi dari (Ghozali, 2017) dengan menghitung composite reliability dimana hasil yang didapatkan antara 0.866 sampai 0.907 dan memenuhi persyaratan yang minimalnya 0.7 (Hair et al., 2014) Tabel 2 Model Pengukuran

\begin{tabular}{|l|l|l|l|}
\hline $\begin{array}{l}\text { Konstruk } \\
\text { dan Item }\end{array}$ & $\begin{array}{l}\text { Cronbach's } \\
\text { alpha }\end{array}$ & CR & AVE \\
\hline PI & 0.877 & 0.907 & 0.620 \\
\hline CS & 0.842 & 0.886 & 0.567 \\
\hline
\end{tabular}


Jurnal Ecodemica, Vol. 4 No. 2 September 2020

\begin{tabular}{|l|l|l|l|}
\hline \hline EOU & 0.836 & 0.884 & 0.60 \\
& 0.807 & & 4 \\
\hline TR & 0.807 & 0.866 & 0.571 \\
\hline
\end{tabular}

Sumber : Hasil Olahan Data (2020)

Selanjutnya Tabel 3 menyatakan bahwa uji validitas diskriminan telah terpenuhi yaitu nila akar AVE lebih besar dari pada nilai korelasi antar variabel.

Tabel 3. Kriteria Fornel-Larcker

\begin{tabular}{|c|c|c|c|c|}
\hline & CS & EOU & PI & TR \\
\hline CS & 0.753 & & & \\
\hline EOU & 0.552 & 0.777 & & \\
\hline PI & 0.636 & 0.634 & 0.787 & \\
\hline TR & 0.518 & 0.312 & 0.495 & 0.756 \\
\hline
\end{tabular}

Sumber : Hasil Olahan Data (2020)

\section{Model Struktural}

Tahap model structural dengan menghitung $\mathrm{R}^{2}$, uji collinearity serta uji hipotesis. Semakin besar nilai $\mathrm{R}^{2}$,maka semakin bagus prediksi konstruk eksogen terhadap konstruk endogen.

Tabel 4 menerangkan bahwa konstruks customer satisfaction sebesar $43.7 \%$ dan $56.3 \%$ dijelaskan variabel lainnya serta purchase intention sebesar $55.3 \%$ dan $44.7 \%$ dijelaskan variabel lainnya yang tidak termasuk dalam model penelitian.

Tabel 4. Pengujian $\mathrm{R}^{2}$

\begin{tabular}{|c|c|c|}
\hline & $\mathrm{R}^{2}$ & Adjusted $\mathrm{R}^{2}$ \\
\hline CS & 0.437 & 0.432 \\
\hline PI & 0.553 & 0.548 \\
\hline
\end{tabular}

Sumber : Hasil Olahan Data (2020)

Pengujian berikutnya adalah mengenai uji collinerarity yaitu untuk menganalisis apakah model penelitian mempunyai kecenderungan collinearity. Batas nilai VIF lebih dari 5.0, maka terdapat kecenderungan collinearity (Hair et al., 2014) Tabel 5 memperlihatkan bahwa nilai VIF pada model di bawah 5.0 sehingga disimpulkan bahwa tidak terdapat collinearity pada model

Tabel 5. Pengujian Collinearity

\begin{tabular}{|c|c|c|}
\hline & CS & PI \\
\hline CS & & 1.775 \\
\hline EOU & 1.108 & 1.439 \\
\hline
\end{tabular}

\begin{tabular}{|l|l|l|}
\hline TR & 1.108 & 1.369 \\
\hline
\end{tabular}

Sumber : Hasil Olahan Data (2020)

Selanjutnya pengujian hipotesis dilakukan untuk menganalisis pengaruh antar konstruk didukung atau tidak didukung. Pengujian hipotesis dengan memperhatikan $t_{\text {tabel }}$ sebesar 1.653 (tingkat signifikansi=5\%). Hipotesis adalah hipotesis berarah. Maka pengujian dilakukan dengan one-tailed test. Jika nilai thitung lebih dari 1.65 makan disimpulkan bahwa hipotesis didukung.Tabel 6 memperlihatkan bahwa seluruh hipotesis diterima

Tabel 6. Hasil Pengujian Hipotesis

\begin{tabular}{cccc}
\hline Hipotesis & $\begin{array}{c}\text { Koefisise } \\
\mathrm{n} \text { Jalur }\end{array}$ & $\mathrm{t}_{\text {hitung }}$ & $\begin{array}{c}\text { Keputusa } \\
\mathrm{n}\end{array}$ \\
\hline $\begin{array}{c}\text { H1 : Ease } \\
\text { of Use }\end{array}$ & 0.531 & 10.42 & Diterima \\
merupakan & & 0 & \\
prediktor & & & \\
yang & & & \\
positif dan & & & \\
signifikan & & & \\
atas & & & \\
purchase & & & \\
intention & & & \\
H2 : Ease & 0.432 & 7.893 & Diterima \\
of Use & & & \\
merupakan & & & \\
predictor & & & \\
positif dan & & & \\
signifikan & & & \\
atas & & & \\
customer & & & \\
satisfactio & & &
\end{tabular}
$n$

\begin{tabular}{|c|c|c|c|}
\hline $\begin{array}{c}\text { H3 : Trust } \\
\text { merupakan } \\
\text { predictor } \\
\text { positif dan } \\
\text { signifikan } \\
\text { atas } \\
\text { purchase } \\
\text { intention }\end{array}$ & 0.330 & 7.987 & Diterima \\
\hline $\begin{array}{c}\text { H4: Trust } \\
\text { merupakan } \\
\text { predictor } \\
\text { positif dan } \\
\text { signifikan } \\
\text { atas } \\
\text { Customer } \\
\text { Satisfactio } \\
n\end{array}$ & 0.383 & 6.668 & Diterima \\
\hline
\end{tabular}




\section{Jurnal Ecodemica, Vol. 4 No. 2 September 2020}

\begin{tabular}{|c|c|c|c|}
\hline $\begin{array}{c}\text { H5 : } \\
\text { Customer } \\
\text { satisfactio } \\
n \\
\text { merupakan } \\
\text { predictor } \\
\text { positif dan } \\
\text { signifikan } \\
\text { atas } \\
\text { purchase } \\
\text { intention }\end{array}$ & 0.307 & 5.771 & Diterima \\
\hline
\end{tabular}

Sumber : Hasil Olahan Data (2020)

Hasil pengujian hipotesis pertama ease of use berpengaruh positif dan signifikan terhadap purchase intention adalah hipotesis diterima dan hasil ini sejalan dengan penelitian (Sin et al., 2012) Hasil pengujian hipotesis kedua ease of use berpengaruh signifikan dan positif terhadap customer satisfaction adalah hipotesis diterima dan hasil ini sejalan dengan penelitian (Pham \& Ahammad, 2017) . Hasil pengujian hipotesis ketiga trust berpengaruh signifikan dan positif terhadap purchase intention adalah hipotesis diterima dan hasil ini sejalan dengan penelitian (Choon Ling, K., Bin Daud, D., Hoi Piew, T., Keoy, K. H., \& Hassan, 2011), (Lien, C. H., Wen, M. J., Huang, L. C., \& Wu, 2015), (Rehman et al., 2019). Hasil pengujian hipotesis keempat trust berpengaruh signifikan dan positif terhadap customer satisfaction adalah hipotesis diterima dan hasil ini sejalan dengan penelitian (Martínez, P., \& del Bosque, 2013), (Pappas et al., 2014), (Tahir Jan \& Abdullah, 2014). Hasil pengujian hipotesis kelima customer satisfaction berpengaruh positif dan signifikan terhadap purchase intention adalah hipotesis diterima dan hasil ini sejalan dengan penelitian (Ali, F., \& Ali, 2016), (Alavi et al., 2016), (Herrera \& Blanco, 2011), (Bukhari, S. M. F., Ghoneim, A., Dennis, C., \& Jamjoom, 2013)

\section{PENUTUP}

Berdasarkan penelitian dan analisis serta pengujian hipotesis disimpulkan bahwa ease of use merupakan predictor positif dan signifikan atas purchase intention, ease of use merupakan predictor positif dan signifikan atas customer satisfaction trust merupakan predictor positif dan signifikan atas purchase intention serta trust merupakan predictor positif dan signifikan atas customer satisfaction serta customer satisfaction merupakan predictor positif dan signifikan atas purchase intention dengan demikian seluruh hipotesis tidak ditolak. Melalui hasil dari penelitian ini, disimpulkan bahwa factor kemudahan dalam penggunaan serta kepercayaan memiliki pengaruh yang tinggi terhadap pengguna aplikasi tokopedia, dimana kepercayaan seperti keamanan baik data maupun informasi pelanggan yang bersifat rahasia terjamin dalam aplikasi tokopedia. Kepuasan terjadi setelah kedua faktor diatas terpenuhi, dapat disimpulkan bahwa kepuasan masih bersifat relatif diantara pengguna karena masih banyak factor penentu lainnya yang berpengaruh terhadap kepuasan seperti kecepatan data dan internet. Untuk kemudahan penggunaan, Tokopedia diharapkan dapat terus melakukan pembenahan sistem database yang sudah ada sehingga penggunanya tidak merasa kesulitan dan tidak perlu menunggu lebih lama untuk proses transaksi di Tokopedia. Implikasi dalam penelitian bahwa responden menyatakan ease of use yang baik terkait pada pernyataan responden tentang kemudahan penggunaan situs web Tokopedia, Saran untuk peneliti selanjutnya dapat menambahkan variabel penelitian lainnya serta dapat menggunakan analisis statistic covariance based structural equation modeling yang dapat menguji kelayakan model penelitian.

\section{REFERENSI}

Abd-El-Salam, E. M., Shawky, A. Y., \& El-Nahas, T. (2013). The impact of corporate image and reputation on service quality, customer satisfaction and customer loyalty: testing the mediating role. Case 


\section{Jurnal Ecodemica, Vol. 4 No. 2 September 2020}

analysis in an international service company.

Alavi, S. A., Rezaei, S., Valaei, N., \& Wan Ismail, W. K. (2016). Examining shopping mall consumer decision-making styles, satisfaction and purchase intention. International Review of Retail, Distribution and Consumer Research, 26(3), 272-303. https://doi.org/10.1080/09593969.2 015.1096808

Ali, F., \& Ali, F. (2016). Hotel website quality, perceived flow, customer satisfaction and purchase intention. Journal of Hospitality and Tourism Technology, 7 (2), 213-228. https://doi.org/10.1108/JHTT-022016-0010

Amaro, Suzanne \& Duarte, P. (2015). An integrative model of consumers' intentions to purchase travel online. Tourism Management, 46.

Amin, M., Rezaei, S., \& Abolghasemi, M. (2014). User satisfaction with mobile websites: the impact of perceived usefulness (PU), perceived ease of use (PEOU) and trust. Nankai Business Review International, 5(3), 258-274.

Amin, M., Rezaei, S., \& Abolghasemi, M. (2014). User satisfaction with mobile websites: the impact of perceived usefulness (PU), perceived ease of use (PEOU) and trust. Nankai Business Review International. https://doi.org/10.1108/NBRI-012014-0005

Banjarnahor, J. (2018). Anteseden Customer Satisfaction Dan Dampaknya Pada Purchase Intention. Jurnal Manajemen Dan Pemasaran Jasa, 10(1), 141. https://doi.org/10.25105/jmpj.v10i1. 1680

Bukhari, S. M. F., Ghoneim, A., Dennis, C., \& Jamjoom, B. (2013). The antecedents of travellers'esatisfaction and intention to buy airline tickets online: A conceptual model. Journal of Enterprise Information Management, 26(6), 624-641.

Choon Ling, K., Bin Daud, D., Hoi Piew, T., Keoy, K. H., \& Hassan, P. (2011). Perceived Risk, Perceived Technology, Online Trust for the Online Purchase Intention in Malaysia. International Journal of Business and Management, 6(6), 167-182. https://doi.org/10.5539/ijbm.v6n6p1 67

Eid, M. I. (2011). Determinants Of ECommerce Customer Satisfaction, Trust, And Loyalty In Saudi Arabia. Journal Of Electronic Commerce Research, 12 (1), 78-93.

Ghozali, I. (2017). Model Persamaan Struktural. Konsep dan Aplikasi Dengan Program AMOS 24.0. Update Bayesian SEM. In Model Persamaan Struktural. Konsep dan Aplikasi Dengan Program AMOS 24. Update Bayesian SEM. https://doi.org/10.1016/j.ando.2009. 02.007

Hair, J. F., Sarstedt, M., Hopkins, L., \& Kuppelwieser, V. G. (2014). Partial least squares structural equation modeling (PLS-SEM): An emerging tool in business research. In European Business Review. https://doi.org/10.1108/EBR-102013-0128

Herrera, C. F., \& Blanco, C. F. (2011). Consequences of consumer trust in PDO food products: The role of familiarity. Journal of Product and Brand Management, 20(4), 282296. https://doi.org/10.1108/1061042111 1148306

Hidayat, A. S., \& Kristiana, I. F. (2016). Hubungan Antara Kecerdasan Emosional Dengan Intensi Bermedia Sosial Pada Siswa Sma Negeri 11 Semarang. Empati, 5(4), 694-699.

Jiang, H., \& Zhang, Y. (2016). An investigation of service quality, 


\section{Jurnal Ecodemica, Vol. 4 No. 2 September 2020}

customer satisfaction and loyalty in China's airline market. Journal of Air Transport Management. https://doi.org/10.1016/j.jairtraman. 2016.07.008

Julianto, S. (2012). Pengaruh Perceived Risk dan Customer Satisfaction terhadap Purchase Intention dan Intention to Revisit pada Gramedia Online Surabaya. Widya Mandala Catholic University Surabaya, 3(September), 1-8.

Kirwadi. (2016). Pengaruh Perceived Ease of Use Perceived Usefulness. 6.

Kooli, K., Mansour, K. Ben, \& Utama, R. (2014). Determinants of online trust and their impact on online purchase intention. International Journal of Technology Marketing, 9(3), 305. https://doi.org/10.1504/ijtmkt.2014. 063858

Kundu, S., \& Datta, S. K. (2015). Impact of trust on the relationship of eservice quality and customer satisfaction. EuroMed Journal of Business, 10(1), 21-46.

Laudon, K., dan Laudon, J. (2013). Management Information Systems (Internatio). Pearson Higher Education.

Lien, C. H., Wen, M. J., Huang, L. C., \& Wu, K. L. (2015). Online hotel booking: The effects of brand image, price, trust and value on purchase intentions. Asia Pacific Management Review, 20(4), 210 218.

Martínez, P., \& del Bosque, I. R. (2013). CSR and customer loyalty: The roles of trust, customer identification with the company and satisfaction. InternationalJournal of Hospitality Management, 35, 89-99. https://doi.org/10.3390/su8080815

McKecnie, S., Ganguli, S., \& Roy, S. K. (2011). Generic technology-based service quality dimensions in banking: Impact on customer satisfaction and loyalty. International Journal of Bank
Marketing.

https://doi.org/10.1108/0265232111 1107648

Mirabi, V., Akbariyeh, H., \& Tahmasebifard, H. (2015). A study of factors affecting on customers purchase intention. Journal of Multidisciplinary Engineering Science and Technology (JMEST), 2(1), 267-273.

Montano, D. E., \& Kasprzyk, D. (2015). Theory of reasoned action, theory of planned behavior, and the integrated behavioral model. Health behavior: Theory, research and practice, 4, 67-96.

Nisar, T. M., \& Prabhakar, G. (2017). What factors determine esatisfaction and consumer spending in e-commerce retailing? Journal of Retailing and Consumer Services, 39(July), 135-144. https://doi.org/10.1016/j.jretconser. 2017.07.010

Oliveira, T., Alhinho, M., Rita, P., \& Dhillon, G. (2017). Modelling and testing consumer trust dimensions in e-commerce Part of the Management Information Systems Commons Modelling and testing consumer trust dimensions in ecommerce. Computers in Human Behavior, 71, 153-164.

Orel, F. D., \& Kara, A. (2014). (2014). Supermarket self-checkout service quality, customer satisfaction, and loyalty: Empirical evidence from an emerging market. Journal of Retailing and Consumer Services, 21(2), 118-129.

Ozturk, A. B., Bilgihan, A., Nusair, K., \& Okumus, F. (2016). What keeps the mobile hotel booking users loyal? Investigating the roles of selfefficacy, compatibility, perceived ease of use, and perceived convenience. International Journal of Information Management, 36(6), 1350-1359.

Pappas, I. O., Pateli, A. G., Giannakos, M. N., \& Chrissikopoulos, V. 


\section{Jurnal Ecodemica, Vol. 4 No. 2 September 2020}

(2014). Moderating effects of online shopping experience on customer satisfaction and repurchase intentions. International Journal of Retail and Distribution Management.

https://doi.org/10.1108/IJRDM-032012-0034

Pham, T. S. H., \& Ahammad, M. F. (2017). Antecedents and consequences of online customer satisfaction: A holistic process perspective. Technological Forecasting and Social Change, 124, 332-342. https://doi.org/10.1016/j.techfore.20 17.04.003

Platon, O. E., Iosub, I., \& Ditoiu, M. C. (2014). An analysis of the AIDAT model based on Facebook promotional contests. Procedia Economics and Finance, 15, 15701577.

Pradiani, T. (2018). Pengaruh Sistem Pemasaran Digital Marketing Terhadap Peningkatan Volume Penjualan Hasil Industri Rumahan. Jurnal Ilmiah Bisnis Dan Ekonomi Asia, 11(2), 46-53. https://doi.org/10.32812/jibeka.v11i 2.45

Qureshi, M. N. Z., \& Bhatt, J. (2015). An Assessment of Service Quality, Customer Satisfaction and Customer Loyalty in Life Insurance Corporation of India with Special Reference to Srinagar District of Jammu and Kashmir. 7(8), 60-70.

Rashid, I. M. A., Abdullah, M. F. S., Yusuf, B. N. M., \& Shaari, M. S. (2016). Impact of Service and Food Quality on Customer Satisfaction among Generation $\mathrm{Y}$ for the Fast Food Restaurant in Malaysia. International Journal of Information, Business and Management, 8(1), 51-67.

Rehman, S. U., Bhatti, A., Mohamed, R., \& Ayoup, H. (2019). The moderating role of trust and commitment between consumer purchase intention and online shopping behavior in the context of Pakistan. Journal of Global Entrepreneurship Research, 9(1). https://doi.org/10.1186/s40497-0190166-2

Rodrigues, L. F., Oliveira, A., \& Costa, C. J. (2016). Does ease-of-use contributes to the perception of enjoyment? A case of gamification in e-banking. Computers in Human Behavior, 61, 114-126.

Sin, S. S., Nor, K. M., \& Al-Agaga, A. M. (2012). Factors Affecting Malaysian young consumers' online purchase intention in social media websites. Procedia - Social and Behavioral Sciences. https://doi.org/10.1016/j.sbspro.201 2.03.195

Suki, N. M. (2011). A structural model of customer satisfaction and trust in vendors involved in mobile commerce. International Journal of Business Science and Applied Management, 6(2), 17-30.

Tahir Jan, M., \& Abdullah, K. (2014). The impact of technology csfs on customer satisfaction and the role of trust: An empirical study of the banks in malaysia. Marketing Intelligence and Planning, 32(5), 429-447.

https://doi.org/10.1108/IJBM-112013-0139

Tandon, U., Kiran, R., \& Sah, A. N. (2016). Analysing the complexities of website functionality, perceived ease of use and perceived usefulness on customer satisfaction of online shoppers in India. International Journal of Electronic Marketing and Retailing. https://doi.org/10.1504/IJEMR.201 6.077118

Taufiqurrahman, W. D. S. G. W. (2015). Pengaruh kualitas pelayanan, kebijakan harga terhadap kepuasan dan loyalitas pelanggan pada jasa lapangan Internasional futsal Pekanbaru. Jom FEKON, 2(1), 1- 


\section{Jurnal Ecodemica, Vol. 4 No. 2 September 2020}

18.

Vinjeng Purnama Putri. (2019). Influence Of Trust And Customer Satisfaction On Repurchase Intention At Online Shop In The Facebook.

Wang, Y. H., \& Tsai, C. F. (2014). The relationship between brand image and purchase intention: Evidence from Award Winning Mutual Funds, . 8(2), 27-40.

Wu, W. Y., \& Ke, C. C. (2015). An online shopping behavior model integrating personality traits, perceived risk, and technology acceptance. Social Behavior and Personality.

https://doi.org/10.2224/sbp.2015.43 .1 .85

Xu, J., Cenfetelli, R.T., \& Aquino, K. (2016). Do different kinds of trust matter? An examination of the three trusting beliefs on satisfaction and purchase behavior in the buyerseller context. The Journal of Strategic Information Systems, 25 (1), 15-31.

\section{UCAPAN TERIMA KASIH}

Penulis mengucapkan banyak terima kasih kepada LPPM Universitas Pelita Harapan yang telah memberikan kesempatan melaksanakan penelitian ini dan telah mendanai penelitian ini (P019-FPar/V/2019.)

\section{BIODATA PENULIS}

Juliana lahir di kota Pematangsiantar, Sumatera Utara, adalah Dosen Fakultas Pariwisata Universitas Pelita Harapan Jakarta, mempunyai kompetensi penelitian bidang Tourism Marketing, Consumer Behavior, Human resources management

Themmy Noval lahir di kota Jakarta 15 November 1974 adalah Dosen Pradita Institute. mempunyai ketertarikan penelitian bidang Ekonomi Manajemen dan Kepariwisataan.

Ira Brunchilda Hubner lahir di kota Bandung 27 Februari 1966 adalah Dosen Fakultas Pariwisata Universitas Pelita
Harapan Jakarta.Mempunyai kompetensi di bidang Pariwisata

Innocentius Bernarto merupakan Dosen Fakultas Ekonomi dan Bisnis, Universitas Pelita Harapan. Saat ini mengajar mata kuliah pemasaran jasa, manajemen merek, dan manajemen pendidikan. Pendidikan terakhir Strata 3 diperoleh dari Fakultas Ekonomi dan Bisnis, Universitas Padjadjaran, Bandung. 